\title{
IMPLEMENTASI UNDANG-UNDANG NO. 23 TAHUN 2004 TENTANG PENGHAPUSAN KEKERASAN DALAM RUMAH TANGGA (PKDRT) BERKAITAN DENGAN PRANATA LOKAL DI DESA SOKONG KECAMATAN TANJUNG KABUPATEN LOMBOK UTARA
}

\author{
ZAINI BIDAYA, SH.MH. \& RIZAL UMAMI \\ (Dosen Perserikatan Muhammadiyah)
}

\begin{tabular}{l} 
INFO ARTIKEL \\
Riwayat Artikel: \\
Diterima: 06-09-2016 \\
Disetujui: $30-09-2016$ \\
\\
\hline Kata Kunci: \\
Penghapusan Kekerasan \\
Dalam Rumah Tangga \\
(PKDRT), Undang- \\
undang No.23 Tahun \\
2004, Pranata \\
Lokal/Hukum \\
Adat/Awig-awig.
\end{tabular}

\begin{abstract}
ABSTRAK
Abstrak: Penelitian ini dilakukan dengan tujuan untuk mengetahui dan menganalisis kasus Kekerasan Dalam Rumah Tangga (KDRT) berkaitan dengan Pranata Lokal di Desa Sokong Kecamatan Tanjung Kabupaten Lombok Utara, penelitian ini juga mengurai serta banyak membahas tentang problematika permasalahan kekerasan dalam rumah tangga dengan penyelesaian dari berbagai unsur aturan baik itu aturan adat dan serta kaitannya dengan penyelesaian secara hukum yang diatur dalam Undang-undang Nomor 23 Tahun 2004 tentang Penghapusan Kekerasan Dalam Rumah Tangga (PKDRT) yang di transformasikan ke dalam bentuk hukum positif. Penelitian ini bertujuan untuk (1). Untuk mengetahui bagaimana pelaksanaan Undang-undang No. 23 Tahun 2004 tentang PKDRT dan untuk mengetahui bagaimana hubungan Pranata Lokal kaitannya dengan Penghapusan Kekerasan Dalam rumah Tangga (PKDRT) berdasarkan Undang-Undang No. 23 Tahun 2004 di Desa Sokong Kecamatan Tanjung Kabuapaten Lombok Utara. (2). Untuk mengetahui bagaimana efektifitas pelaksanaan dari Undang-undang No. 23 Tahun 2004 tentang Penghapusan Kekerasan Dalam Rumah Tangga (PKDRT) dan Pranata Lokal di Desa Sokong Kecamatan Tanjung Kabupaten Lombok Utara.

Penelitian ini menggunakan metode kualitatif, pendekatan metode yang digunakan dalam penelitian ini adalah termasuk jenis penelitian hukum empiris normatif, Penelitian ini berlokasi di Desa Sokong Kecamatan Tanjung Kabupaten Lombok Utara. Sumber data adalah data primer dan data sekunder. Metode pengumpulan data diperoleh dari wawancara, studi kepustakaan, dan studi dokumentasi.

Dari hasil penelitian diketahui bahwa Implementasi ketentuan pidana dalam UU No.23 Tahun 2004 Tentang Penghapusan KDRT belum sepenuhnya terlaksana dengan baik, karena masyarakat Desa Sokong lebih mengedepankan Hukum Adat / Pranata Lokal, masyarakat setempat menilai hukum adat lebih tepat kepada nilai religi dan ikatan kemanusiaan terhadap sesama masyarakat setempat, masyarakat juga tidak banyak mengetahui UU No. 23 Tahun 2004 Tentang Penghapusan Kekerasan Dalam Rumah Tangga (PKDRT) yang banyak diperdengarkan dan dipertontonkan dalam penyelesaian kasusnya melalui media cetak dan elektronik.
\end{abstract}

\section{A. LATAR BELAKANG}

Segala bentuk kekerasan, terutama kekerasan dalam rumah tangga merupakan pelanggaran hak azasi manusia dan merupakan kejahatan terhadap martabat manusia serta bentuk-bentuk diskriminasi yang harus dihapuskan. Karena biasanya yang menjadi korban terhadap kekerasan dalam rumah tangga adalah kebanyakan perempuan maka mereka harus mendapatkan perlindungan dari Negara atau masyarakat agar terhindar dari kekerasan atau ancaman kekerasan, penyiksaan, atau perlakuan yang merendahkan derajat dan martabat manusia.

Kekerasan dalam rumah tangga juga bisa terjadi pada anggota keluarga yang menumpang atau tinggal dalam suatu rumah tangga dalam kaitan keluarga. Kekerasan dalam rumah tangga juga menimpa para pembantu rumah tangga.
Kasus-kasus kekerasan dalam rumah tangga kerapkali baru terungkap dan terekspos media ketika korban telah menderita parah secara fisik maupun mental atau bahkan meninggal. Di banyak daerah, termasuk di wilayah Nusa Tenggara Barat masalah Kekerasan Dalam Rumah Tangga (KDRT) (domestic violence) dari waktu kewaktu semakin meningkat. Komisi Nasional (Komnas) Perempuan membeberkan kasus kekerasan dalam rumah tangga (KDRT) yang terjadi di Nusa Tenggara Barat (NTB) selama 2011 mencapai 256 kasus kekerasan, di Desa Sokong terdapat beberapa kasus yang terjadi diantaranya kekerasan dalam rumah tangga terdiri dari 7 kasus, 4 kasus pelecehan seksual serta percobaan perkosaan, data ini berdasarkan catatan pemerintah desa sokong kecamatan tanjung kabupaten lombok utara (http://www.ntbterkini.com/2012/10/19/kdrt-di-ntbcapai-256-kasus/). 
Jumlah yang terungkap tidaklah menunjukkan angka sebenarnya. Karena kasus kekerasan dalam rumah tangga ibarat gunung es. Jumlah yang tercatat dan terekspos jauh lebih besar, untuk itu diperlukan penegak hukum yang berwenang untuk menindas tegas setiap perbuatan masyarakat yang bertentangan dengan hukum yang berlaku, baik itu merupakan usaha pencegahan yang bersifat preemtif (pencegahan yang dilakukan secara dini melalui kegiatan-kegiatan edukatif dengan sasaran mempengaruhi faktor-faktor penyebab, pendorong dan faktor peluang dari terjadinya pengguna untuk menciptakan sesuatu kesadaran dan kewaspadaan serta daya tangkap guna terbinanya kondisi perilaku dan norma hidup), preventif (pengawasan dan pengendalian) maupun refresif (Merupakan upaya penindakan dan penegakan hukum terhadap ancaman faktual dengan sangsi yang tegas dan konsisten sesuai dengan undangundang yang berlaku untuk membuat efek jera bagi pelaku tindak kekerasan dalam rumah tangga).

Besarnya angka tindak kekerasan dalam rumah tangga di Indonesia membuat pemerintah Indonesia membuat undang-undang (UU) tentang Penghapusan Kekerasan Dalam Rumah Tangga pada tanggal 22 September 2004 lalu bangsa Indonesia secara resmi memiliki UU penghapusan kekerasan dalam rumah tangga. UU ini Disahkan menjadi UU Republik Indonesia No. 23 Tahun 2004 tentang Pengahapusan Kekerasan Dalam Rumah Tangga (Lembaran Negara Republik Indonesia Tahun 2004 Nomor 95, tambahan Lembaran Negara Republik Indonesia Nomor 4419).

Keberadaan UU No. 23 Tahun 2004 sangat penting sebagai dasar hukum untuk membantu para korban kekerasan dalam rumah tangga sekaligus menghukum pelakunya. UU No. 23 Tahun 2004 juga diharapkan membantu mencegah terjadinya kekerasan dalam rumah tangga. Yang menjadi masalah, belum banyak orang yang mengetahui keberadaan UU yang mengatur tentang Penghapusan Kekerasan Dalam Rumah Tangga ini. Dengan demikian maka perlu dilakukan suatu upaya atau terobosan untuk menyebarluaskan undang-undang ini ke masyarakat luas.

Selain UU No. 23 Tahun 2004, di masingmasing daerah juga terdapat peraturan-peraturan lokal atau pranata lokal (hukum adat) yang dapat dijadikan acuan untuk melindungi perempuan dan anak-anak. Walaupun tidak secara khusus membahas tentang kekerasan yang terjadi dalam rumah tangga. Namun dengan adanya pranata lokal ini diharapkan dapat dijadikan payung hukum bagi masyarakat setempat.

Pranata lokal atau hukum adat, tiap-tiap daerah mempunyai rambu-rambu tersendiri seperti hukum adat yang terdapat di Desa Sokong Kecamatan Tanjung Kabupaten Lombok Utara. Peraturan atau hukum adat yang terdapat di Desa Sokong ini disebut "Awig-Awig". Peraturan ini hanya berlaku di wilayah Desa Sokong. Awig-awig ini lahir karena dilatar belakangi karena adanya kasus-kasus yang sifat melanggar tatanan kehidupan masyarakat yang sudah ada (seperti kasus perkawinan, perkelahian dalam keluarga, irigasi kamtibmas dan lain-lain), kemajemukan masyarakat (Islam, Hindu, Budha) dan Awig-awig ini dibuat berdasarkan kesepakatan seluruh warga Sokong untuk mengatur kehidupan masyarakat. Awig-awig ini sekarang telah dijadikan aturan untuk menyelesaikan pelanggaran di tingkat Desa, dan kalau memang tidak bisa selesai di tingkat Desa baru di selesaikan ke pengadilan. Dan adanya Awig-awig ini, masyarakat Desa setempat menjadi lebih berhati-hati dalam berbuat yang nantinya melanggar aturan.

Harapan masyarakat dengan adanya Awig-awig ini adalah adanya pandangan yang lebih baik terhadap kasus-kasus yang ada di Desa Sokong terutama yang berkaitan dengan kasus-kasus dalam keluarga seperti perkelahian dalam keluarga atau Kekerasan Dalam Rumah Tangga (KDRT) dan masalah lainnya serta menajdi solusi yang tepat dan cepat dalam mengatasi masalah Kekerasan Dalam Rumah Tangga (KDRT).

Berdasarkan pemikiran inilah yang mendorong penulis untuk mengkaji dan melakukan penelitian tentang Pelaksanaan Undang-Undang No. 23 Tahun 2004 Tentang Penghapusan Kekerasan Dalam Rumah Tangga (PKDRT) Berkaitan dengan Pranata Lokal Di Desa Sokong Kecamatan Tanjung Kabupaten Lombok Utara.

\section{B. METODE PENELITIAN}

\section{A. Metode yang digunakan}

Metode yang digunakan dalam penelitian ini adalah termasuk jenis penelitian hukum empiris normatif, penelitian hukum empiris normatif ini menggunakan dua metode penelitian, yaitu penelitian empiris dan penelitian normatif.

a) Penelitian hukum empiris adalah metode penelitian yang dilakukan untuk mendapatkan data primer dan menemukan kebenaran dengan menggunakan metode berfikir induktif dan kriterium kebenaran koresponden serta fakta yang digunakan untuk melakukan proses induksi dan pengujian kebenaran secara koresponden adalah fakta yang mutakhir (Sedarmayanti \& Syarifudin. 2002 : hal 14).

b) Dalam (Prof. Abdulkadir Muhammad, 2004 : 101) dijelaskan bahwa:

"penelitian hukum normatif adalah metode penelitian hukum yang dilakukan dengan meneliti bahan pustaka atau data sekunder belaka dan mengkaji hukum tertulis dari berbagai aspek, yaitu aspek teori, sejarah, filosofi, perbandingan dan komposisi, lingkup dan materi, konsistensi, penjelasan umum dan pasal demi pasal, formalitas dan kekuatan mengikat suatu undang-undang serta bahasa hukum yang digunakan, tetapi tidak mengkaji aspek terapan atau implementasinya. Karena tidak tidak mengkaji aspek terapan atau implementasi, maka penelitian hukum normatif sering disebut "penelitian hukum dogmatik" atau "penelitian hukum teoritis" (dogmatic or theoretical law research).

Menurut Prof. Abdulkadir Muhammad, "hukum normatif empiris (applied normatif law) adalah perilaku nyata (in action) setiap warga sebagai akibat keberlakuan hukum normatif. Perilaku tersebut dapat di observasi dengan nyata dan merupakan bukti kesesuaian perilaku dengan ketentuan hukum normatif.

Jadi, Penelitian hukum dengan menggunakan pendekatan empiris normatif yaitu penelaahan dan pengkajian terhadap peraturan perundangundangan, peraturan pemerintah dan kebijakankebijakan lain yang berkaitan dengan Undangundang No. 23 Tahun 2004 (Penghapusan 
32 CIVICUS I Pendidikan Pancasila dan Kewarganegaraan Kekerasan Dalam Rumah Tangga) kemudian dilanjutkan dengan penelitian terhadap data primer dilapangan atau pada masyarakat yang berkaitan dengan Undang-undang No. 23 Tahun 2004 yaitu di Desa Sokong Kecamatan Tanjung Kabupaten Lombok Utara.

\section{B. Subjek Penelitian}

Menurut Sugiyono (2005:299), menyatakan bahwa subyek penelitian dalam penelitian ini adalah sebagai berikut:

"Dalam penelitian kualitatif tidak menggunakan populasi, karena penelitian kualitatif berangkat dari kasus tertentu yang ada pada situasi sosial tertentu dan hasil kajiannya tidak akan diberlakukan ke populasi, tetapi ditransferkan ketempat lain pada situasi sosial yang memiliki kesamaan dengan situasi sosial pada kasus yang dipelajari”.

"Sampel dalam penelitian kualitatif bukan dinamakan responden, tetapi sebagai narasumber, atau partisipan, informen, teman dan guru dalam penelitian. Sampel dalam penelitian kualitatif, juga bukan disebut sebagai sampel statistik, tetapi sampel teoritis, karena tujuan penelitian kualitatif adalah untuk menghasilkan teori. Sampel dalam penelitian kualitatif juga disebut sebagai sampel konstruktif, karena dengan sumber data dari sampel itu dapat dikonstruksikan fenomena yang semula masih belum jelas".

Dalam penelitian kualitatif, tehnik sampling yang sering digunakan adalah purposive sampling, Seperti telah dikemukakan bahwa, purposive sampling adalah tehnik pengambilan sampel sumber data dengan pertimbangan tertentu. Pertimbangan tertentu ini misalnya orang yang mengalami masalah tersebut sehingga akan memudahkan peneliti menjelajahi obyek atau situasi soasial yang diteliti ( Sanipah, 2005:301).

Berdasarkan hal tersebut diatas dapat disimpulkan bahwa, penentuan tehnik sampel dalam penelitian menggunakan tehnik purposive sampling. Tehnik purposive sampling ini merupakan tehnik sampel yang membeberkan data yang lebih lengkap dan merata yaitu orang-orang yang mengalami masalah kekerasan dalam rumah tangga, maka subyek penelitian dalam penelitian atau narasumbernya adalah masyarakat yang terkena kasus kekerasan dalam rumah tangga serta pendukung lainnya yang diantaranya kepala desa, kepala dusun, pemangku adat, tokoh agama, serta tokoh masyarakat dan lain sebagainya

\section{Metode Pengumpulan Data \\ 1. Observasi}

Metode Observasi adalah studi yang disengaja dan sistematis tentang fenomena sosial dan gejala-gejala alam dengan cara pengamatan dan pencatatan (Yatim Riyanto, 2001:27). Jadi observasi bermaksud untuk mengumpulkan data yang merupakan verbalisasi dari hal-hal yang telah diamati. Bisa juga diartikan bahwa observasi adalah metode penelitian atau suatu penyelidikan yang menggunakan alat indra secara lansung terhadap fakta-fakta atau gejala yang ada.

Jadi dalam penelitian ini observasi digunakan untuk mengamati secara lansung situasi sosial, untuk memperoleh data yang aktual dan sistematik mengenai kekerasan dalam rumah tangga berkaitan dengan pranata lokal di desa sokong kecamatan tanjung kabupaten lombok utara pada tahun 2013 atau dengan
Vol. 4, No. 2, September 2016, hal 30-39

kata lain meneliti menggunakan tehnik observasi partisipatif.

\section{Wawancara}

Wawancara adalah bentuk komunikasi secara lansung antara dua orang, melibatkan seseorang yang ingin memperoleh informasi dan seseorang lain yang memiliki informasi dengan mengajukan pertanyaanpertanyaan tertentu berdasarkan tujuan tertentu (Mulyana, 2001:108)

Adapun dalam penelitian ini digunakan wawancara tidak terstruktur di mana wawancara bersifat luwes tanpa teks yang harus diikuti. Wawancara ini memakai kata-kata pertanyaan yang dapat diubah saat wawancara, dengan penyesuaian kebutuhan dan situasi saat wawancara, dengan catatan tidak menyimpang dari informasi yang di butuhkan untuk peneltian ini.

Pengumpulan data dilakukan dengan tehnik wawancara dengan responden dengan alat bantu form kuisioner (Daftar pertanyaan mengenai UU No. 23 tahun 2004 yang berkaitan dengan Pranata Lokal di desa Sokong) dan tehnik studi pustaka yaitu dengan cara mencari dan mengumpulkan bahan-bahan kepustakaan yaitu mengkaji perundang-undangan dan buku-buku refrensi yang berhubungan dengan masalah tersebut.

Tehnik pengambilan data ini digunakan khususnya untuk mengambil data secara lansung dari sumber yang mengetahui fenomena secara lansung atau merupakan pelaku dalam fenomena tersebut.

\section{Dokumentasi}

Dalam Arikunto (2006:113), menyatakan bahwa dokumentasi berasal dari kata "dokumen" yang artinya barang-barang tertulis. Sehingga dalam buku tersebut dijelaskan bahwa metode dokumentasi adalah mencari data mengenai hal-hal atau variable yang berupa catatan, buku transkrip, surat kabar, prasasti, notulen rapat, agenda dan sebagainya.

Dari pengertian diatas maka dapat disimpulkan bahwa metode dokumentasi adalah cara untuk mendapatkan data-data berupa laporan tertulis dari suatu peristiwa yang terdiri dari penjelasan dan pikiran terhadap suatu pikiran ketentuan-ketentuan, foto-foto dan dokumen-dokumen lain yang ada kaitannya dengan data penelitian.

\section{A. Analisa Data \\ 1. Reduksi Data}

Proses pemilihan pemusatan perhatian pada penyederhanaan, pengabstrakan dan transformasi data kasar yang muncul dari catatan tertulis yang dimaksud adalah instrument penelitian yang dibagikan kepada subyek penelitian. Reduksi data berlansung terus menerus secara penelitian, sesudah penelitian lapangan sampai laporan tersusun. Dengan kata lain reduksi data merupakan suatu bentuk analisis yang menajamkan, menggolongkan, mengarahkan, membuang yang tidak perlu untuk mengorganisasikan data dengan cara sedemikian rupa sehingga kesimpulan finalnya dapat ditarik atau diambil. Data yang diambil adalah Pelaksanaan Undang-undang No.23 Tahun 2004 Tentang Penghapusan Kekerasan Dalam Rumah Tangga (PKDRT) Berkaitan Dengan Pranata Lokal Di Desa Sokong Kecamatan Tanjung Kabupaten Lombok Utara.

\section{Penyajian Data}

Tahap kedua dari kegiatan analisis data adalah penyajian data, penyajian data adalah sekumpulan informasi menjadi konsep rasional sesuai dengan 
kenyataan sehingga memungkinkan menarik kesimpulan. Data-data yang telah diambil dan telah direduksi akan disajikan secara deskripsi dimana hasil wawancara diubah bahasanya menjadi kalimat yang lebih baku dan mudah dimengerti serta dikaitkan dengan teori-teori sesuai dengan hasil wawancara dan observasi.

\section{Penarikan Kesimpulan}

Kegiatan analisis yang ketiga adalah menarik kesimpulan. Penarikan kesimpulan dilakukan dalam bentuk membuat kesimpulan hasil penelitian yang dituangkan dalam bentuk pembahasan. Dalam alur ini merupakan kegiatan untuk mengambil kesimpulan terhadap hasil penelitian yang telah dilakukan atau proses penarikan kesimpulan akhir dari data yang telah diambil.

\section{HASIL DAN PEMBAHASAN}

\section{Deskripsi Data}

\section{a) Demografi}

lokasi penelitian yaitu Desa Sokong Kecamatan Tanjung Kabupaten Lombok Utara. Desa Sokong adalah salah satu desa di wilayah Kecamatan Tanjung yang berada disebelah barat kecamatan Tanjung. Jarak dari kecamatan ke Desa Sokong $\pm 2 \mathrm{~km}$, sedangkan dari kabupaten $\pm 1,5 \mathrm{~km}$.

b) Sistem Pengaturan Kekerasan Dalam Rumah Tangga (KDRT) Yang Dianut Dalam UU Nomor.23 Tahun 2004

Sebelum lahirnya UU No. 23 Tahun 2004, Kekerasan Dalam Rumah Tangga (KDRT) tidak diatur dalam Undang-undang itu tersendiri. Dalam KUHP pun istilah Kekerasan Dalam Rumah Tangga tidak dikenal secara khusus. KUHP hanya mengatur secara terbatas mengenai ruang lingkup Kekerasan Dalam Rumah Tangga (KDRT), sebagaimana yang diatur dalam pasal 351-356 KUHP, yang mengatur mengenai penganiayaan (mishandeling), yang berarti hanya terbatas pada kekerasan fisik.

Istilah Kekerasan Dalam Rumah Tangga (KDRT), sangat penting untuk dikemukakan dan diatur secara khusus dalam sebuah Undang-undang, mengingat Undang-undang yang ada saat ini belum mampu memberikan protection (perlindungan). Attention (perhatian), secara khusus terhadap terjadinya Kekerasan Dalam Rumah Tangga (KDRT). Selain itu, ideologi harmonisasi keluarga yang selama ini ditanamkan dalam benak masyarakat maupun aparat hukum, sehingga tidak menganggap serius adanya Kekerasan Dalam Rumah Tangga (KDRT), atau menganggap rumah tangga sebagai masalah privat saja.

Mengingat masalah Kekerasan Dalam Rumah Tangga (KDRT), tidak lagi harus dianggap sebagai masalah privat saja, tetapi masalah publik yang harus ditangani secara serius oleh semua kalangan. Maka pemerintah berupaya membuat perangkat hukum baru yang mengatur secara khusus mengenai Kekerasan Dalam Rumah Tangga (KDRT), sebagai upaya untuk mencegah terjadinya tindak Kekerasan Dalam Rumah Tangga (KDRT). Serta untuk menciptakan ketenangan, ketertiban dalam kehidupan bermasyarakat, berbangsa dan bernegara.

Dalam rangka untuk meningkatkan pengendalian dan pengawasan serta menciptakan upaya mencegah, melindungi terjadinya tindak Kekerasan Dalam Rumah Tangga (KDRT), diperlukan pengaturan dalam bentuk Undang-undang yang baru, yang berazaskan keimanan dan ketaqwaan terhadap Tuhan Yang Maha Esa, manfaat keseimbangan, keserasian, keselarasan, keadilan dan kesetaraan gender, non diskriminasi dan perlindungan korban dalam hal prikehidupan hukum, serta penghormatan terhadap nilai-nilai Hak Asasi Manusia.

Dalam mengingat ketentuan baru dalam Konvensi Perserikatan Bangsa-Bangsa Tentang Penghapusan Segala Bentuk Kekerasan Terhadap Perempuan tahun 1993. Dan Conventin on the Eliminatin of all Form of Discrimination Against Women (CEDAW) tahun 1995, yang telah diratifikasi dengan Undang-undang Nomor 7 tahun 1984, tentang pengesahan Konvensi mengenai Penghapusan Segala Bentuk Diskriminasi Terhadap Wanita.

Dengan demikian, Undang-undang Nomor 23 tahun 2004 diharapkan lebih efektif mencegah dan menanggulangi terjadi tindak Kekerasan Dalam Rumah Tangga (KDRT), termasuk perlindungan terhadap korban Kekerasan dalam lingkup rumah tangga.

Namun demikian, kita menyadari bahwa Undang-undang ini pun belum mampu memberikan proteksi terhadap terjadinya tindak Kekerasan Dalam Rumah Tangga (KDRT), karena dari hari ke hari dari informasi media cetak maupun elektronik peningkatan secara kuantitas maupun kualitas tindak pidana Kekerasan Dalam Rumah Tangga (KDRT) di wilayah hukum Republik Indonesia semakin memprihatikan.

Dari gambaran tersebut di atas, penulis akan melihat tentang subtansi dari pengaturan Kekerasan Dalam Rumah Tangga (KDRT) dalam Undang-undang Nomor 23 tahun 2004. Yang selanjutnya akan dianalisis kembali tentang sisi kelemahan dan sisi kelebihan yang terkandung di dalamnya.

Dalam Undang-undang Nomor 23 tahun 2004 tentang Penghapusan Kekerasan Dalam Rumah Tangga (PKDRT), terdiri dari $10 \mathrm{Bab}$ yang pengaturannya sebagai berikut :
1) Bab I : Ketentuan Umum
2) Bab II : Asas Dan Tujuan
3) Bab III : Larangan Kekerasan Dalam Rumah Tangga
4) Bab IV : Hak-Hak Korban
5) Bab V :Kewajiban Pemerintah Dan Masyarakat
6) Bab VI : Perlindungan
7) Bab VII : Pemulihan Korban
8) Bab VIII : Ketentuan Pidana
9) Bab IX : Ketentuan Peralihan
10) Bab X : Ketentuan Penutup
Dari pengaturan tersebut di atas akan penulis uraikan hal-hal yang khusus berkaitan dengan larangan Kekerasan Dalam Rumah Tangga (KDRT), hak-hak korban, serta ketentuan pidananya sebagai berikut :

\section{c) Pelaksanaan Penghapusan Kekerasan Dalam Rumah Tangga (PKDRT) dalam Perspektif UU No. 23 Tahun 2004}

Dalam Bab II pasal 4 Undang-undang Nomor 23 tahun 2004, bahwa pengaturan Penghapusan Kekerasan Dalam Rumah Tangga (PKDRT) bertujuan untuk :

1) Mencegah segala bentuk kekerasan dalam rumah tangga; 
2) Melindungi korban kekerasan dalam rumah tangga;

3) Menindak pelaku kekerasan dalam rumah tangga;

4) Memelihara keutuhan rumah tangga yang harmonis dan sejahtera.

Berdasarkan Pasal 4 tersebut, bahwa larangan kekerasan dalam rumah tangga dimaksudkan untuk mencegah segala bentuk kekerasan, melindungi korban, menindak pelaku serta memelihara keutuhan rumah tangga yang harmonis dan sejahtera.

Oleh karena itu, tindak kekerasan dalam rumah tangga perlu disangsikan lagi bahwa segala perbuatan yang bertentangan dengan maksud dari ketentuan tersebut merupakan suatu kejahatan, meskipun secara kongkrit dalam undang-undang ini tidak disebutkan sebagai kejahatan. Lebih lanjut dalam Pasal 5 Bab III, Undang-undang Nomor 23 tahun 2004, mempertegas tentang larangan dangan cara kekerasan fisik, kekerasan psikis, kekerasan seksual, atau penelantaran keluarga.

Namun di dalam pelaksanaannya di Desa Sokong Kecamatan Tanjung Kabupaten Lombok Utara, tidak berjalan sesuai dengan apa yang dicita-citakan dalam Undang-undang No. 23 Tahun 2004, karena menurut penuturan Amaq Nuriyasah selaku kepala dusun Prawira, "kami umumnya dan saya khususnya tidak mengerti dan tidak memahami sebagaimana yang tertera didalam peraturan pemerintah tentang Penghapusan Kekerasan Dalam Rumah Tangga atau Undang-undang yang mengaturnya, kami hanya mengetahui itu pada media cetak dan media televisi yang banyak menimpa artis, orang-orang kaya dan kaum terpelajar, kami hanya memberlakukan Hukum Adat bila terjadi suatu pelanggaran adat didalam wilayah kami tentunya di Desa Sokong ini”

Amaq Nuriyasah menambahkan bahwa peran penegak hukum dalam hal ini pihak pemerintah dan kepolisian tentunya sangat minim sekali dalam hal menyelesaikan perkara Kekerasan Dalam Rumah Tangga dan masalah-masalah yang lain yang menjadi problematika masyarakat desa Sokong baik itu masalah kekerasan fisik maupun kekerasan psikis.

Untuk lebih jelasnya penulis akan menguraikan tentang kekerasan dalam ketentuan Pasal 5 tersebut. Kekerasan fisik sebagaimana dimaksud dalam Pasal 5 huruf (a), adalah : "Perbuatan yang mengakibatkan rasa sakit, jatuh sakit, atau luka berat.”

Kekerasan psikis sebagaimana yang dimaksud dalam Pasal 5 huruf (b), adalah "Perbuatan yang mengakibatkan ketakutan, hilangnya rasa percaya, dan atau penderitaan psikis berat pada seseorang."

Kemudian kekerasan seksual sebagaimana yang dimaksud dalam Pasal 5 huruf (c), meliputi :

a. Pemaksaan hubungan seksual yang dilakukan terhadap orang yang menetap dalam lingkup rumah tangga tersebut;

b. Pemaksaan hubungan seksual terhadap salah seorang dalam lingkup rumah tangganya dengan orang lain untuk tujuan komersial dan atau tujuan tertentu.

Dan yang dimaksud dengan penelantaran rumah tangga dalam Pasal 9 yaitu :

a. Setiap orang dilarang menelantarkan orang dalam lingkup rumah tangganya, padahal menurut hukum yang berlaku baginya atau karena persetujuan atau perjanjian ia wajib memberikan kehidupan,

pemeliharaan kepada orang tersebut.

perawatan,

b. Penelantaran sebagaimana yang dimaksud pada ayat (1) juga berlaku bagi setiap orang yang mengakibatkan ketergantungan ekonomi dengan cara membatasi dan atau melarang untuk bekerja yang layak di dalam atau diluar rumah, sehingga korban berada di bawah kendali orang tersebut.

Dari rumusan Pasal ini memberikan batasan yang jelas mengenai kekerasan yang dilarang oleh hukum, berupa kekerasan fisik, kekerasan psikis, seksual dan penelantaran rumah tangga, yang tidak dapat ditawar lagi. Karena segala perbuatan yang bertentangan dengan ketentuan ini merupakan suatu kejahatan.

\section{d) Pengaturan Hak-Hak Korban dan Upaya Kepolisian Dalam Pencegahan Serta Penyelesaian Kekerasan Dalam Rumah Tangga (KDRT). \\ Rumusan pengaturan hak-hak korban termuat} pada Pasal 10 yang pada pokoknya mengatur hal-hal sebagai berikut :

a. Perlindungan dari pihak keluarga, kepolisian, kejaksaan, pengadilan, advokat, lembaga sosial, atau pihak lainnya baik sementara maupun berdasarkan penetapan perintah perlindungan dari pengadilan;

b. Pemberian pelayanan kesehatan sesuai dengan kebutuhan medis;

c. Mendapatkan penanganan secara khusus berkaitan dengan kerahasiaan korban;

d. Pendampingan oleh pekerja sosial dan bantuan hukum pada setiap tingkat proses pemeriksaan sesuai dengan ketentuan peraturan perundangundangan; dan

e. Korban berhak mendapatkan pelayanan bimbingan rohani.

Selain itu, Undang-undang Nomor 23 tahun 2004, mencantumkan mekanisme yang didasarkan pada kebutuhan dan kepentingan korban, yang pokok sebagai berikut :

a. Kewajiban masyarakat dan negara untuk melindungi korban;

b. Perintah perlindungan terhadap korban serta perintah pembatasan gerak sementara terhadap pelaku;

c. Bantuan hukum bagi korban;

d. Perlindungan saksi;

e. Prosedur alternatif pengajuan tuntutan;

f. Prosedur pembuktian yang tidak mempersulit korban, kesaksian korban dapat dipakai dan diperbuat oleh keterangan ahli maka perkara bisa terus diajukan hingga ke penuntutan;

g. Alat pembuktian menetapkan pula Visum Psikiatrikum; dan,

h. Adanya penanganan secara integratif/terpadu dari intansi hukum, instansi medis atau instansi pemerintah lainnya dan lembaga-lembaga sosial kemasyarakatan.

"Berdasarkan data yang penyusun dapatkan, kasus-kasus Kekerasan Dalam Rumah Tangga yang ditangani oleh AKP. Arief Hidayat, SIK Selaku Kapolsek tanjung pada tahun 2011 ada 21 kasus, dan tahun 2012 ada 35 kasus. Menurut beliau bahwa kasus-kasus kekerasan ini dari tahun ke tahun mengalami 
peningkatan, tetapi kasus-kasus tersebut masih kita bisa tangani dan kita selesaikan secara kekeluargaan sehingga tidak sampai ke meja hijau, ungkapnya."

"Namun sebagai upaya untuk penanganan terhadap korban tindak kekerasan khususnya dalam rumah tangga Polri dalam hal ini Kapolsek Tanjung, melakukan kegiatan sebagaimana yang diatur dalam tugas pokoknya, yang tercantum dalam Pasal 13 Undang-undang Nomor 2 Tahun 2002 tentang Kepolisian Negara RI.

Yang disebutkan bahwa tugas pokok Polri adalah : Memelihara keamanan dan ketertiban masyarakat; Menegakan Hukum; dan Memberikan perlindungan, pengayoman dan pelayanan kepada Masyarakat. Adapun kegiatan tersebut dirangkai melalui kegiatan yang bertujuan untuk mencegah sedini mungkin sehingga tidak terjadi kekerasan terhadap perempuan (Upaya Prepentif) tindakan pencegahan melalui upaya Preventif dan kegiatan penindakan melalui upaya Represif. Bentuk kegiatan Polri tersebut adalah :

1) Upaya Pre-Emtif :

a. Memberikan penyuluhan untuk tidak melakukan tindak kekerasan terhadap perempuan, melalui peranan tokoh agama dan tokoh masyarakat.

b. Meningkatkan partisipasi masyarakat untuk mau memberikan informasi tentang adanya tindak kekerasan kepada Polri.

2) Upaya Preventif :

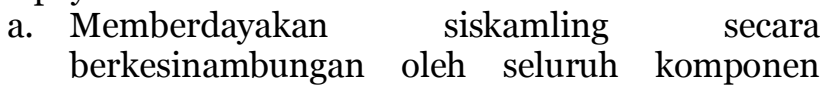
masyarakat.

b. Melakukan patroli secara rutin di daerah rawan kriminalitas.

c. Menyediakan tempat khusus yang memberikan pelayanan kepada korban tindak kekerasan.

3) Upaya Represif

Melakukan penegakan hukum terhadap para pelaku yakni tindak kekerasan secara proporsional dan profesional melalui kegiatan penyelidikan, penyidikan hingga pelimpahan berkas perkara ke Jaksa Penuntut Umum. Terhadap upaya Penegakan hukum, Polri berpedoman pada Ketentuan Perundang-undangan yang berlaku seperti :

UU No. 23 Tahun 2004 tentang Penghapusan Kekerasan Dalam Rumah Tangga (PKDRT).

UU No. 23 Tahun 2002 tentang Perlindungan Anak.

UU No. 1 Tahun 1946 tentang KUHP.

UU No. 8 Tahun 1981 tentang KUHAP.

"Kepolisian Republik Indonesia sudah jelas akan melaksanakan supremasi hukum secara profesional, proporsional dan prosedural dengan tetap memperhatikan dan menegakkan HAM. Untuk mewujudkan komitmen tersebut, beberapa upaya telah dilakukan oleh Kapolsek Tanjung antara lain :

a. Penyediaan Ruang Pelayanan Khusus (RPK);

b. Penyediaan Pusat Pelayanan Terpadu (PPT) di RS Tanjung secara gratis bagi korban Kekerasan;

c. Melakukan Pendidikan dan pelatihan bagi Awak RPK dan PPT;

d. Melaksanakan kerjasama dan kordinasi dengan instansi pemerintah dan pemertintah dalam penanganan korban tindak kekerasan dan pekerja migran; dan e. Memprioritaskan penanganan perkara perempuan melalui upaya Pro Justiti (Proses Hukum) dan Non Justitia (Mediasi).

"Namun, apa yang menjadi komitmen Polri tersebut tentunya tidak akan dapat terwujud tanpa adanya peran serta dan dukungan dari masyarakat. Untuk itu kami berharap agar masyarakat"

a. Bersedia untuk melaporkan diri bila mengalami atau mengetahui bahwa telah tejadi Tindak Pidana kekerasan terhadap dirinya atau orang lain; Karena tindak kekerasan pada beberapa Pasal dalam Undang-undang Penghapusan Kekerasan Dalam Rumah Tangga (PKDRT) merupakan delik aduan. Seperti yang disebutkan dalam Pasal 51 yang berbunyi : Tindak Kekerasan Fisik sebagaimana dimaksud dalam Pasal 44 ayat (4) merupakan delik aduan; Pasal 52, berbunyi : Tindak pidana kekerasan psikis sebagaimana yang dimaksud dalam Pasal 44 ayat (2) merupakan delik aduan; dan pada Pasal 53 yang berbunyi : Tindak pidana kekerasan seksual sebagaimana yang dimaksud dalam Pasal 46 yang dilakukan oleh suami terhadap istri atau sebaliknya merupakan delik aduan;

b. Mau dengan tulus untuk memenuhi panggilan sebagai saksi dalam penanganan kasus kekerasan terhadap perempuan; karena dalam ketentuan Undang-undang Penghapusan Kekerasan Dalam Rumah Tangga (PKDRT), bahwa sebagai salah satu alat bukti yang sah, keterangan seorang saksi korban saja sudah cukup untuk membuktikan bahwa tedakwa bersalah, apabila disertai dengan suatu alat bukti yang sah lainnya. Seperti Visum dan keterangan ahli.

c. Memberikan informasi yang diperlukan Polri untuk tuntasnya penanganan perkara yangditangani;

d. Menyampaikan kepada masyarakat luas berkaitan dengan masalah kekerasan terhadap perempuan khususnya dalam rumah tangga; dan

e. Tidak mudah terpengaruh terhadap informasi yang tidak jelas sumbernya.

Dari rumusan di atas, dapat diketahui bahwa setiap korban Kekerasan Dalam Rumah Tangga (KDRT), wajib mendapat perlindungan hukum sebagai upaya untuk membantu mengatasi persoalan yang dialami oleh Korban Kekerasan Dalam Rumah Tangga (KDRT). Hakhak korban ini sebelumnya tidak diatur dalam KUHP. Ketentuan inilah yang memberikan nilai lebih bagi Undang-undang Penghapusan Kekerasan Dalam Rumah Tangga (PKDRT), sehingga dengan adanya jaminan hakhak korban ini, akan membantu perlidungan korban Kekerasan Dalam Rumah Tangga (KDRT).

Di Desa Sokong penanganan kasus-kasus KDRT umumnya menggunakan pranata lokal yakni melalui Majelis Krama Desa/Adat, dalam arti bila terjadi kasuskasus KDRT, maka upaya penyelesaian yang lebih didahulukan adalah menggunakan pranata lokal tersebut, dan bila kasus KDRT tidak bisa diselesaikan dengan pranata lokal melalui jalur Majelis Krama Desa/Adat maka kasus ini akan diselesaikan melalui jalur formal yakni kepolisian yang menggunakan Undang-undang No. 23 Tahun 2004 sebagai acuan/pedoman.

Di Kepolisian setelah korban melapor, maka upaya dari pihak Kepolisian untuk menyelesaikan kasus tersebut secara damai di desa, bila kedua belah pihak setuju maka di tingkat desa upaya penyelesaian kasus 
36 CIVICUS I Pendidikan Pancasila dan Kewarganegaraan atau masalah tersebut menggunakan pranata lokal/awig-awig itu sendiri.

\section{e) Pengaturan Kekerasan Dalam Rumah Tangga Yang Dianut Dalam Pranata Lokal (Awig-awig) Desa Sokong Kecamatan Tanjung Kabupaten Lombok Utara. \\ Dalam Undang-undang Dasar Republik} Indonesia 1945 ditegaskan tentang eksistensi satuansatuan masyarakat hukum, adat istiadat dan hak-hak tradisional masyarakat Indonesia, adalah sebagai suatu bagian yang integral dari bangsa Indonesia sebagai sebuah identitas yang mencerminkan keberadaannya ditengah bangsa-bangsa di dunia dan sebagai aset nasional yang harus dipelihara dan dikembangkan.

Salah satu tujuan nasional yang ditegaskan dalam Pembukaan UUD 1945 adalah melindungi segenap bangsa Indonesia dan seluruh tumpah darah Indonesia. Frasa "segenap bangsa Indonesia" menunjuk pada pengakuan atas realitas keragaman, yang semuanya harus mendapatkan perlindungan. Namun, pengakuan pada tataran konstitusional tersebut tidak selalu sejalan realitas penyelenggaraan kehidupan berbangsa. Eksistensi masyarakat hukum adat belum pernah mendapatkan perhatian nyata. Kebijakan sebelum reformasi lebih mengarah kepada sentralisasi dan penyeragaman yang meminggirkan,bahkan tidak mengakui eksistensi kesatuan masyarakat hukum adat.

Pasal 28I Ayat (3) UUD 1945 menjamin identitas budaya dan hak masyarakat tradisional selaras dengan perkembangan zaman dan peradaban. Pengakuan dan penghormatan tersebut tidak hanya terhadap identitas budaya, juga terhadap eksistensinya sebagai subyek hukum. Hal itu ditegaskan dalam Pasal 18B Ayat (2) UUD 1945 yang menyatakan bahwa negara mengakui dan menghormati kesatuan-kesatuan masyarakat hukum adat beserta hak-hak tradisionalnya sepanjang masih hidup dan sesuai perkembangan masyarakat dan prinsip Negara Kesatuan Republik Indonesia, yang diatur dalam undang-undang.

Ketentuan konstitusional tersebut memiliki dua unsur penting. Pertama adalah jaminan pengakuan dan penghormatan kesatuan masyarakat hukum adat dan hak-hak tradisionalnya. Sementara unsur kedua adalah pembatasan,yaitu sepanjang masih hidup dan sesuai perkembangan masyarakat serta prinsip Negara Kesatuan Republik Indonesia (NKRI), yang nantinya diatur dalam undang-undang. Kedua unsur tersebut akan menjadi landasan untuk menentukan kriteria suatu kesatuan masyarakat dapat disebut kesatuan masyarakat hukum adat yang akan diatur dalam undang-undang.

Penjelasan itu juga yang mewakili pemerintah desa beserta perangkat-perangkatnya serta Tokoh agama, Tokoh Masyarakat, Pemuka Adat, Tokoh Pemuda dan Masyarakat Desa Sokong kecamatan Tanjung Kabupaten Lombok Utara menjadi latar belakang begitu kentalnya masyarakat setempat memegang dan mematuhi hukum adat yang dibuat atas dasar kesepakatan bersama, sehingga dalam sedikit ruang masalah apapun harus diselesaikan dengan musyawarah dan menekankan hukum adat dalam proses penyelesaiannya.

Di desa Sokong, segala macam permasalahan yang terjadi pada kawasan masyarakat tersebut baik itu masalah tanah, perairan, perkawinan dan lain sebagainya termaktub dan terbahas di dalam Majelis Krama Adat desa Sokong, sehingga proses perjalanan daripada hukum adat tersebut bisa berjalan dengan
Vol. 4, No. 2, September 2016, hal 30-39

lancar walaupun di dalam desa sokong ini banyak terdapat perbedaan, baik dari segi agama, keyakinan, ras dan lain sebagainya tetapi dalam pelaksanaannya awigawig ini sangat berjalan dengan efektif.

f) Pelaksanaan Penghapusan Kekerasan Dalam Rumah Tangga (PKDRT) dalam Perspektif Pranata Lokal/Hukum Adat/Awig-awig.

Atas dasar penjelasan tersebut diatas pranata lokal yang penulis maksud awig-awig Desa Sokong yang terbentuk dari norma-norma, serta adat istiadat setempat, merupakan hukum yang mengatur dan mengikat masyarakat Desa Sokong. Awig-awig ini (Awigawig Desa Sokong) mengatur semua aspek, baik tentang pelanggaran pidana seperti halnya dengan Kekerasan Dalam Rumah Tangga (KDRT). Dalam Awig-awig ini secara khusus pasal yang mengatur tentang pelanggaran terhadap UU No. 23 tahun 2004 ini memang tidak ada. Seperti pada sepakat 11 E (adat tapsila), sepakat 15, sepakat 20, sepakat 34 .

Sepakat $11 \mathrm{e}$ :

Barang siapa dengan sengaja mengumpat dan atau sejenisnya terhadap orang lain diancam dengan hukuman bila bibir, sanksinya duang tali samas skeet (2.450 UB).

Sepakat 15 :

Ngilm Pati adalah suatu tindakan/perbuatan melawan hukum yang mengakibatkan orang lain menjadi korban.

Sepakat 20 :

Bila bibir adalah suatu ucapan melawan hukum yang diucapkan oleh seorang atau kelompok orang atas orang lain yang mengakibatkan orang/kelompok tesebut tersinggung.

Sepakat 34 :

Luputing tangan adalah suatu perbuatan seorang laki-laki memegang, perempuan yang bukan muhrimnya dan atau gampang memukul orang lain.

Dari ke empat sepakat tersebut di atas tidak ada secara khusus di uraikan pasal tentang pelanggaran terhadap UU No. 23 Tahun 2004 tentang Penghapusan Kekerasan Dalam Rumah Tangga (PKDRT). Jika kita melihat pengaturan tentang hal ini dalam KUHP, juga tidak ada pasal secara khusus yang mengatur tentang tindak pidana ini. Dalam KUHP sifat pengaturannya dalam tersebar dalam beberapa pasal.

Secara umum undang-undang No. 23 Tahun 2004 memang masih sangat dini untuk dikenal oleh semua lapisan masyarakat khususnya masyarakat Desa Sokong terlebih lagi adanya anggapan bahwa fiksi hukum itu memang masih berlaku di Indonesia. Sejak sejak diundangkannya baik secara langsung maupun tidak langsung, Undang-undang ini telah berlaku bagi seluruh rakyat Indonesia. Undang-undang No. 23 Tahun 2004 belum dikenal di Desa Sokong karena belum pernah dilakukan sosialisasi baik oleh pihak pemerintah desa maupun pihak yang berwenang.

Menurut Bapak Ripsah, S.Pd selaku Kepala Desa Sokong, "Masyarakat Desa Sokong khususnya kebanyakan tidak mengetahui tentang Undang-undang ini dalam arti laporan tentang tindak kekerasan dalam rumah tangga ini memang ada yang telah melaporkan yakni dalam kurun waktu 2011 sampai sekarang hanya mempunyai empat kasus dari tindak pidana ini yang dilaporkan ke krama adat desa sokong, begitu ungkapan beliau.

Lebih Lanjut juga dikatakan oleh Bapak Kepala desa yaitu dari kasus-kasus tersebut kami tidak ingin hal 
tersebut terulang lagi di wilayah hukum desa kami, Karen itu akan mencemarkan nama baik kami juga didesa ini. Kami akan memperketat hukum adat dan segera akan menambahkan hukuman yang sekiranya setimpal untuk siapapun yang melakukan tindakan kekerasan dan ataupun kejahatan ketika dia berada di wilayah hukum kami, begitu penuturan Bapak Ripsah, S.Pd.

Dari Penuturan Bapak Kepala Desa Sokong Kecamatan Tanjung Kabupaten Lombok Utara, sekalipun mereka melapor pada pihak kepolisian tetapi mereka tidak tahu sudah ada aturan khusus yang mengatur tentang kasus mereka yakni Undang-undang No. 23 Tahun 2004. Setelah mereka melapor, pihak kepolisian wajib menanyakan kepada korban apakah akan melanjutkan perkara atau tidak. Akan tetapi pihak kepolisian wajib menyarankan untuk diselesaikan di tingkat desa secara kekeluargaan menurut awig-awig yang berlaku di desa tersebut. Pihak desa dalam hal ini, dalam kasus-kasus PKDRT yang telah dilaporkan kepada pihak kepolisian harus mampu menyelesaikan perkara tersebut dengan aturan desa yakni awig-awig desa yang di pakai. Dan bila tejadi pengulangan kasus, maka majelis krama adat desa akan musyawarah kembali untuk memutuskan hukuman yang setimpal dengan awig-awig.

Dalam menyelesaikan kasus-kasus kekerasan dalam rumah tangga, perangkat desa sebagai tonggak terdepan dalam pemerintahan di desa akan mengumpulkan majelis krama adat desa dan pihak berperkara di balai desa untuk menyelesaikan perkara tersebut, dipimpin oleh ketua majelis adat desa dan dibantu oleh para anggota.

Secara umum dalam kenyataannya Undangundang No. 23 Tahun 2004 tentang KDRT ini di desa sokong belum bisa berjalan/berlaku seperti apa yang kita harapkan. Ketidak berlakuan secara utuhnya dari undang-undang ini disebabkan karena belum pernah dilakukan sosialisasi dari Undang-undang No. 23 Tahun 2004. Jadi dapat dikatakan Undang-undang No. 23 Tahun 2004 masih dalam masa transisi.

Faktor diatas dapat memperjelas dominannya pranata lokal (awig-awig) digunakan untuk penyelesaian kasus KDRT di Desa Sokong karena memang dalam kenyataannya awig-awig ini lebih akrab dan melekat pada diri setiap warga Desa Sokong.

Dari uraian di atas dapat kita melihat hubungan antara undang-undang No. 23 Tahun 2004 dengan pranata lokal (awig-awig) Desa Sokong adalah saling menunjang dan seiring sejalan, disatu sisi UU No. 23 Tahun 2004 secara Nasional berlaku diseluruh Indonesia dan mempunyai kekuatan memaksa dan mengikat, di sisi lain awig-awig Desa Sokong merupakan kearifan lokal yang sangat akrab dengan masyarakat setempat. kedua aturan ini meskipun berbeda sumber tetapi pada hakekat merupakan aturan yang mengatur dan mengikat masyarakat.

g) Tata Cara Penyelesaian Serta Bentuk Pencegahan Kasus kekerasan Dalam Rumah Tangga Berdasarkan Majelis Tata Krama Adat Desa Sokong Kecamatan Tanjung Kabupaten Lombok Utara

Dalam menyelesaikan perkara permasalahan yang terjadi di Desa Sokong Kecamatan Lombok Utara, ada beberapa hal yang kemudian ditempuh oleh para pemangku kebijakan yang ada di dusun dan di desa sokong baik itu oleh Kepala Desa, Kepala Dusun, Tokoh Agama, Tokoh Masyarakat, Tokoh Pemuda Serta Majelis Krama adat yaitu :

a. Dengan melakukan Musyawarah Adat yang kemudian akan merumuskan dan melihat kembali awig-awig serta menentukan konteks permasalahan apa yang dilanggar dari kesepakatan adat tersebut.

b. Majelis Krama Adat mengajukan damai kepada kedua belah pihak yang bersengketa

c. Ketika permasalahan tidak selesai kemudian para pemangku adat menawarkan bentuk penyelesaian dan bentuk ganti rugi yang diinginkan oleh pihak yang dirugikan.

d. Kemudian ketika tidak bisa tercapai kesepakatan antara kedua belah pihak yang bersengketa di tingkat dusun lalu permaslahan tersebut akan diselesaikan ditingkat desa dengan mempertimbangkan berbagai aturan dan kesepakatan adat

e. Jika kemungkinan permasalahan tersebut tidak juga kunjung selesai di tingkat desa maka kewajiban pihak pemerintah desa membawa permaslahan ini ketingkat kepolisian.

Dari runutan proses penyelesaian permaslahan tersebut bisa kita lihat bagaimana masyarakat setempat sangat menghargai kebijakan dan menghormati peraturan desa yang disepakati bersama.

Adapun proses pencegahan yang dilakukan oleh para pemangku kebijakan dan Majelis Krama Adat desa Sokong yaitu :

a. Dengan melakukan berbagai proses pemberian pemahaman dampak yang akan ditimbulkan ketika melakukan kasus kekerasan tersebut yang diantaranya diberikan disetiap acara keagamaan atau pengajian bagi agama tertentu dan disetiap masing-masing keyakinan yang dianut masyarakat.

b. Dengan melakukan gotong royong dan kegiatan keagamaan

c. Memperbanyak silaturahim antar umat beragama

d. Menebarkan kasih sayang terhadap sesama

e. Dan dengan menambah sanksi serta ganti rugi ketika terjadi permasalahan seperti kasus kekerasan dan lain sebagainya sehingga akan menimbulkan efek jera bagi pelakunya.

Inilah yang menjadi tugas masyarakat setempat dalam melaksanakan serta mewujudkan masyarakat desa sokong yang aman, tentram dan berbudi pekeri luhur seperti yang diungkapkan oleh Nuriyasah selaku Kepala Dusun Prawira Desa Sokong Kecamatan Tanjung Kabupaten Lombok Utara.

\section{h) Efektivitas Pelaksanaan Undang-Undang Nomor 23 Tahun 2004 Tentang Penghapusan Kekerasan Dalam Rumah Tangga (PKDRT) dan Pranata Lokal di Desa Sokong Kecamatan Tanjung Kabupaten Lombok Utara.}

Banyaknya perundang-undangan yang diprodak oleh Badan Legislatif Negara merupakan salah satu ciri masyarakat modern dewasa ini. Tetapi tidak selalu masyarakat mengenal identitas pengaturan oleh hukum seperti halnya dengan Undang-undang No. 23 Tahun 2004 ini. Sejak berlakunya hanya orang-orang tertentu saja yang mengetahui keberadaannya terlebih lagi undang-undang ini masih belum bisa mencapai seluruh 
38 CIVICUS | Pendidikan Pancasila dan Kewarganegaraan pelosok negeri. dari perkembangannya yang diteliti oleh penulis khususnya di Desa Sokong Kecamatan Tanjung Kabupaten Lombok Utara, ketidak tahuan masyarakat tentang undang-undang ini sangat memperihatinkan jika kita mengingat akan efektivitas dan hasil yang menjadi tujuan dari sebuah peraturan dibuat. Menurut hasil wawancara penulis dengan perangkat Desa Sokong Kecamatan Tanjung Kabupaten Lombok Utara, yang terdiri dari kepala desa (Bapak Ripsah, SP), kepala dusun, ketua RT, tokoh pemuda, tokoh masyarakat dan tokoh adat bahwa mereka tidak telalu tahu dan memahami baik isi maupun substansi dari undangundang No. 23 Tahun 2004 ini.

Walaupun akhir-akhir ini kasus-kasus PKDRT cukup marak dibicarakan di media masa baik elektronik maupun media cetak dengan banyaknya pelanggaran yang dilakukan terhadap Undang-undang No. 23 Tahun 2004 oleh para artis dan pejabat sehingga terkesan lebih diketahui oleh masyarakat luas, akan tetapi masyarakat Desa Sokong tidak mengerti dari isi berita yang ditayangkan media cetak maupun elektronik tersebut dan menganggap kekerasan dalam rumah tangga sebagai sesuatu yang tabu untuk diketahui orang banyak.

Selama ini masyarakat Desa Sokong, dalam menyelesaikan kekerasan yang terjadi dalam rumah tangga umumnya menggunakan cara penyelesaian tradisional dengan menggunakan pemuka masyarakat, kepala adat, dan agama atau sesepuh keluarga yang didasar pada awig-awig desa yang telah mereka buat dan sepakati bersama. Awig-awig ini telah melembaga dan membudaya dikalangan masyarakat Desa Sokong karena peran figur-figur di atas sangat dipandang efektif dalam penyelesaian sengketa.

Dalam teori hukum, ada tiga dasar atau landasan dalam pembuatan segala peraturan, pada tiap jenis dan tingkat yang harus dipenuhi agar suatu peraturan atau undang-undang berjalan dengan efektif yaitu :

\section{Landasan filosofis}

Landasan filosofis yaitu dasar filsafat atau pandangan atau ide yang menjadi dasar cita-cita sewaktu menuangkan hasrat dan kebijaksanaan (pemerintahan) kedalam suatu rencana atau draf peraturan Negara.

2. Landasan yuridis

Landasan yuridis ialah ketentuan hukum yang menjadi dasar hukum (rechtsgrond) bagi pembuatan suatu peraturan.

3. Landasan politis

Landasan politis ialah garis kebijaksanaan politik yang menjadi dasar selanjutnya bagi kebijaksanaankebijaksanaan dan pengarahan ketatalaksanaan pemerintahan negara.

Dari teori di atas, efektivitas Undang-undang No. 23 Tahun 2004 khususnya di Desa Sokong Kecamatan Tanjung Kabupaten Lombok Utara berkenaan dengan landasan politis, efektivitas undang-undang ini belum memuaskan. Dalam BAB V Undang-undang No. 23 Tahun 2004 tentang kewajiban pemerintah dan masyarakat pasal 11, pasal 12 ayat (1), (2), (3), pasal 13, dan pasal 14 belum terpenuhi oleh pemerintah meskipun hal ini adalah kebutuhan undang-undang ini untuk keefektifannya.

Intinya, Undang-undang No.23 Tahun 2004 di desa sokong belum efektif, dikarenakan masyarakat yang belum mengetahui secara jelas dan rinci mengenai peraturan tersebut, sehingga berdampak pada efektifitas
Vol. 4, No. 2, September 2016, hal 30-39

pelaksanaan serta penegakan hukum, juga dikarenakan masyarakat lebih memilih menyelesaikan suatu perkara dengan menggunakan hukum adat/pranata local/awigawig karena dinilai lebih memberikan efek yang lebih dari pada sanksi hukum dari pengadilan/pemerintah, sehingga kesannya seperti ketidak percayaan masyarakat terhadap hukum positif dan termasuk didalamnya pelaksanaan Undang-undang No. 23 Tahun 2004 tentang Penghapusan Kekerasan Dalam Rumah Tangga.

\section{SIMPULAN DAN SARAN}

\section{Kesimpulan}

Dari hasil penelitian maka dapat di kesimpulan sebagai berikut :

a) Undang-undang No. 23 Tahun 2004 tentang Kekerasan Dalam Rumah Tangga (KDRT) secara umum sudah berlaku secara Nasional, begitu juga halnya undangundang ini di Desa Sokong Kecamatan Tanjung Kabupaten Lombok Utara seiring dengan berjalannya pelaksanaan awig-awig desa. Akan tetapi dari kenyataan yang ada undang-undang ini sangat jarang digunakan untuk penyelesaian kasus-kasus kekerasan dalam rumah tangga yang ada. Hubungan antara Undang-undang No. 23 Tahun 2004 dengan pranata lokal (awig-awig) Desa Sokong adalah saling menunjang dan seiring sejalan, disatu sisi UU No. 23 Tahun 2004 secara Nasional berlaku diseluruh Indonesia dan mempunyai kekuatan memaksa dan mengikat, di sisi lain awig-awig Desa Sokong merupakan kearifan lokal yang sangat akrab dengan masyarakat setempat. Kedua aturan ini meskipun berbeda sumber tetapi pada hakekat merupakan aturan yang mengatur dan mengikat.

b) Undang-undang No. 23 Tahun 2004 Desa Sokong Kecamatan Tanjung Kabupaten Lombok Utara secara umum tidak bisa dilaksanakan secara efektif. Hal ini disebabkan ketidaktahuan masyarakat tentang undangundang ini dan kebutuhan dari Undang-undang No. 23 Tahun 2004 untuk efektifitasnya yang diatur dalam pasalpasalnya juga belum terpenuhi di Desa Sokong. Penanganan kasus-kasus KDRT di Desa Kosong umumnya menggunakan pranata lokal yakni melalui Majelis Krama Desa/Adat, bila kasus KDRT tidak bisa diselesaikan melalui jalur formal yakni kepolisian yang menggunakan Undang-undang No. 23 Tahun 2004 sebagai 2004 sebagai acuan/pedoman umumnya.

\section{Saran-saran}

Saran yang dapat penulis sampaikan dalam penelitian ini adalah sebagai berikut :

a) Pemerintah Provinsi NTB dan Kabupaten Lombak Utara sebagai perpanjangan tangan pemerintah pusat, harus dapat membuat terobosan baru tentang pengaturan Penghapusan Kekerasan Dalam Rumah Tangga (PKDRT) dalam bentuk PERDA dan mensosialisasikan Undangundang No. 23 Tahun 2004 sehingga dikenal luas oleh masyarakat.

b) Masyarakat diharapkan untuk berpatisipasi dalam memberikan informasi, komunikasi dan edukasi dengan pemerintah atau pihak yang berwajib mengenai terjadinya tindak pidana Kekerasan Dalam Rumah Tangga (KDRT), sehingga mempermudah menindak setiap pelaku kejahatan Kekerasan Dalam Rumah Tangga (KDRT).

c) Penyelesaian perkara tindak pidana Kekerasan Dalam Rumah Tangga (KDRT) yang menggunakan Hukum Adat (awig-awig) harus mampu memberikan keadilan kepada 
masyarakat setempat yang berperkara dan tidak bertentangan dengan Undang-undang No. 23 Tahun 2004.

d) Peran tokoh agama, tokoh masyarakat, tokoh pemuda, dan lembaga non pemerintah yang peduli dalam pencegahan Kekerasan Dalam Rumah Tangga (KDRT), berkewajiban mensosialisasikan, sehingga masyarakat mempunyai kesadaran akan pentingnya penataan terhadap normanorma yang berlaku dalam masyarakat. 